\title{
Does Riparian Filtration Reduce Nutrient Movement in Sandy Agricultural Catchments?
}

\author{
Robert Summers ${ }^{1}$, David Weaver ${ }^{2}$, Nardia Keipert ${ }^{3} \&$ Jesse Steele ${ }^{4}$ \\ ${ }^{1}$ Department of Agriculture and Food, Western Australia, WAROONA, Western Australia, Australia \\ ${ }^{2}$ Department of Agriculture and Food, Western Australia, ALBANY, Western Australia, Australia \\ ${ }^{3}$ Peabody Energy Australia, 14/259 Queen Street Brisbane 4000, Australia \\ ${ }^{4}$ Newmont Mining Corporation Elko, Nevada 89801, Australia \\ Correspondence: Robert Summers, Department of Agriculture and Food, Western Australia, 120 South Western \\ Highway, WAROONA, Western Australia. Tel: 61-8-9733-7777. E-mail: robert.summers@agric.wa.gov.au
}

\author{
Received: August 28, 2014 Accepted: September 16, 2014 Online Published: September 30, 2014 \\ doi:10.5539/enrr.v4n4155 URL: http://dx.doi.org/10.5539/enrr.v4n4p155
}

\begin{abstract}
Fencing and re-vegetating the banks of agricultural drains is a widely used practice thought to improve drainage water quality. Monitoring of small nested headwater catchments draining sections with fencing and vegetation (Veg), and without fencing (UF) showed that after scraping the base of the drain in the Veg catchment, the phosphorus (P) and sediment concentration was lower than the UF section. When the site was revisited 9 years later this study showed the Veg drain lost a third of the sediment load of the UF drain but the Total Phosphorus (TP) per unit area load from the Veg drain was approximately 3 times higher than the UF drain. The Veg drain also had a higher TP and Filterable Reactive Phosphorus (FRP) concentration than the UF drain. The impact on nitrogen was variable but both the Total Nitrogen $(\mathrm{TN})$ and nitrate $\left(\mathrm{NO}_{3}\right)$ concentration were higher from the Veg drain than from the UF drain. This suggests that the absence of fencing and the presence of livestock in the UF section allowed streamflow to mobilise and importantly, expose sediment, which adsorbed soluble forms of $\mathrm{P}$ that was retained in the drain. The vegetation within the fenced area appeared to have little impact on $\mathrm{P}$ or sediment loss. Other techniques that favour chemical retention by $\mathrm{P}$ sorption rather than physical filtration would need to be employed to reduce $\mathrm{P}$ loads in these sandy catchments where soluble $\mathrm{P}$ forms dominate.

The $\mathrm{P}$ concentration in the Veg section dropped relative to the UF section after later treatment with a $30 \mathrm{~mm}$ layer of cracked lateritic gravel but it was less effective than the earlier excavation of the bed of the Veg section of the drain, exposing the clay subsoil. The increase in P retention from the gravel is likely to be short lived because the $\mathrm{P}$ sorption capacity of the gravel was exhausted in 12 months.
\end{abstract}

Keywords: riparian vegetation, water quality, nutrients, phosphorus, nitrogen, sediment

\section{Introduction}

The water quality of the Peel Inlet and Harvey Estuarine system has declined since the 1950's. The estuarine system has been recognized by the Western Australian Environmental Protection agency as being in need of urgent catchment-wide waterway protection and enhancement for the purpose of water quality protection (Environmental Protection Agency, 2008). The eutrophication of the estuary through excess phosphorus (P) inputs has been well reported in several studies pointing to the need to control the losses from the surrounding catchment (McComb \& Davis, 1993; Hodgkin, Birch, Black, \& Humphries, 1980).

The use of riparian buffers to improve water quality and reduce the impacts of surrounding agriculture has been attributed to the process of retaining nutrient laden sediment from surface runoff water through vegetative filtering (Osborne \& Kovacic, 1993, Hoffmann et al., 2009) and by direct stabilisation of the drainage system (Thorne, 1990).

Riparian buffers have been investigated under similar conditions of sandy soils and in a similar environment south of the Peel-Harvey near Albany in Western Australia (McKergow, Weaver, Prosser, Grayson \& Reed, 2003; McKergow, Prosser, Weaver, Grayson, \& Reed, 2006ab). The riparian vegetation had a dramatic effect on suspended sediment but had little impact on Total P (TP) concentration or load. McKergow et al. (2003) found 
there was a change in the form of $\mathrm{P}$ in streamflow from $50 \%$ particulate $\mathrm{P}(\mathrm{PP})$ prior to riparian management to $25 \% \mathrm{PP}$ after riparian management that had improved riparian vegetation. This aspect of overestimating the impact of riparian buffers has been noted in reviews which emphasize the impact of the dissolved forms of $\mathrm{N}$ and $\mathrm{P}$ bypassing riparian buffers in overland and subsurface flow (Drewry, Newham, Greene, Jakeman, \& Croke, 2006, Hoffmann, Kjaergaard, Uusi-Kämppäc, Hansend, \& Kronvang, 2009).

A study of water quality over one winter in 1997 in the Peel-Harvey reported 30 to $60 \%$ retention of $P$, which was attributed to stream riparian management (Cronin, 1998). To understand the mechanisms that may have led to these large reported differences in water quality response for catchments with sandy soils, the study site of Cronin (1998) was revisited and re-assessed. This paper reports on the reassessment of the impact of stream riparian management on water quality over 4 years using automated monitoring equipment. Following this the drain was treated with cracked lateritic gravel to simulate the exposure of $P$ retentive sediments using a different medium and without the removal of existing sediments.

\section{Materials and Methods}

A small ephemeral headwater ditch that drained an area of 171 ha was monitored at 2 points equipped with automatic water samplers. The 2 points allowed the measurement of water quality differences arising from an upstream fenced and vegetated section of drain (Veg), and a downsteam unfenced and unvegetated section of drain (UF). The upstream part of the drainage system (Veg) had $720 \mathrm{~m}$ of drain that had been fenced $10 \mathrm{~m}$ either side in 1993 and vegetated with native shrubs and trees on one side. The other side of the Veg drain was used as an access track if drain maintenance was required, and this access section was vegetated with volunteer grasses. The Veg drain catchment was 80 ha, of which 39 ha was actively-draining (Figure 1). Minor revegetation of the steep stream bank and to a lesser extent in the stream bed occurred through volunteer weeds and pasture species as a result of stock exclusion. It should be noted that although there was considerably more vegetation in the drain bed of the Veg section than the UF section, no attempt to introduce wetland or riparian plant species was made. Upstream of the Veg drain was an area of predominantly native vegetation (41 ha out of the 80 ha upstream catchment). A drain had been constructed through this area of native vegetation to drain a small area of farmland upstream, however due to the relatively low rainfall and high water use of the native vegetation, this section of the catchment did not flow at any point in the monitoring period and contributed no water to the upstream monitoring point. Below the upstream monitoring point, the drain then flowed into another $860 \mathrm{~m}$ section of drain that was unfenced (UF) and grazing cattle had full access to the drain throughout the year. This UF drain had a catchment of 91 ha when the Veg drain catchment was excluded. The ephemeral drainage system was monitored over 6 winters from 2006 to 2011. During summer there was no flow and the drainage system dried up. The landuse surrounding the drain was cattle grazing. Different landholders managed each catchment and an estimate of the fertilizer application was made for the catchment.

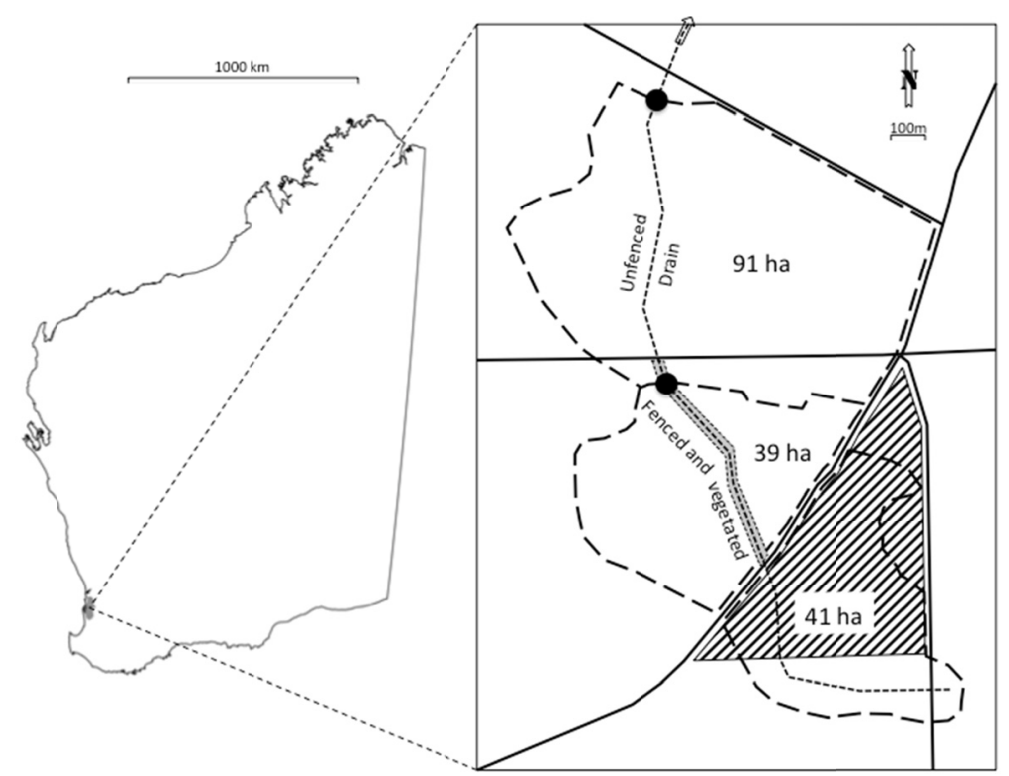

Figure 1. Location and layout of the site showing the gauging stations as filled circles on the drain. Areas of natural vegetation areas are shaded 
In 2010 cracked lateritic pea gravel was applied to the base of entire section of the Veg drain to a depth of 30 $\mathrm{mm}$. The cracked gravel was screened to between 3 and $5 \mathrm{~mm}$ and a total of 20 tonnes was applied. The base of the drain was approximately 1 metre wide and $745 \mathrm{~m}$ long. The pea gravel was analysed for P sorption and compared with results from whole gravel separated from agricultural soils (Weaver et al., 1992). The P sorption was markedly greater in the cracked gravel which showed at $50 \mathrm{mg} \mathrm{P} \mathrm{L}^{-1}$ solution the $\mathrm{P}$ sorbed was $488 \mathrm{mg} \mathrm{kg}^{-1}$ and $60 \mathrm{mg} \mathrm{kg}^{-1}$ for the cracked gravel and the natural gravel respectively. The $\mathrm{P}$ sorption isotherm for the cracked pea gravel indicated a $\mathrm{P}$ sorption of $369 \mathrm{mg} \mathrm{P} \mathrm{kg}^{-1}$ of gravel at an equilibrium solution concentration of $1 \mathrm{mg} \mathrm{P}$ $\mathrm{L}^{-1}$ (similar to the $\mathrm{P}$ concentration in the drain water).

Most of the surface flow from the paddocks into the Veg drain occurred through small feeder drains that concentrated the flow from the paddock, thereby limiting wide-scale interaction of surface flow with the vegetated strip. The vegetated strip was slightly elevated by spoil from drain maintenance, although much of the spoil had been removed during construction and maintenance prior to planting the vegetation. Most interaction between the drainage water and vegetation was through the limited amount of volunteer grasses and weeds that had colonized the banks and to a lesser extent the drain bed. The spoil from construction and maintenance of the UF section of drain had not been removed at any time and resulted in a low, eroded bank, from intermittently dispersed spoil on either side of the shallow drain. The upstream Veg section of drain was more deeply incised than the lower UF section of drain. Both sections of drain were incised through the sandy upper layer and down to a clay layer of the duplex soil below, i.e. the upstream Veg section of drain had approximately 300 to $500 \mathrm{~mm}$ more sandy soil profile than the lower UF section which had an upper sandy layer of $500 \mathrm{~mm}$.

In the catchment of the upstream Veg section of drain, $\mathrm{P}$ was surface applied annually at $17 \mathrm{~kg} \mathrm{P} \mathrm{ha}^{-1}$ as superphosphate with $12 \mathrm{~kg} \mathrm{P} \mathrm{ha}^{-1}$ applied in May and $5 \mathrm{~kg} \mathrm{P} \mathrm{ha}^{-1}$ in August. Nitrogen was applied in August at 25 to $35 \mathrm{~kg} \mathrm{~N} \mathrm{ha}^{-1}$. In the UF section of drain, the adjacent paddocks were not fertilized in 2006 and 2007 and from 2008 to 2011 they applied $17 \mathrm{~kg} \mathrm{P} \mathrm{ha}^{-1}$ of in June.

Records from 1984 and 1985 show plant available or bicarbonate extractable P (Colwell, 1965) were 42 and $36 \mathrm{mg}$ $\mathrm{kg}^{-1}$ on average at the UF and Veg sites respectively. Ammonium oxalate extractable iron (Tamm, 1922) was 765 and $341 \mathrm{mg} \mathrm{kg}^{-1}$ on average at the UF and Veg sites, respectively. Both catchments soils can be described as having high $\mathrm{P}$ concentrations, and contained almost twice as much plant available $\mathrm{P}$ as was required for pastures to achieve $90 \%$ of maximum pasture production (Bolland et al., 2010).

The water quality of the sites had previously been monitored for one winter in 1997 (Cronin, 1998) for the same parameters monitored here but using manual sampling on a weekly basis. Indeed this site was chosen because of the previous study and to more closely monitor the impact of the stream fencing and riparian establishment.

Automatic water samplers and water level recorders (Teledyne, ISCO 6712, Lincoln NE USA) were installed at the upstream and downstream sites. Samplers were programmed to measure water height (stage) every 15 minutes using a flow bubbler module. The channel cross-section was surveyed at each site to determine the area and discharge at each stage height measurement, and discharge was calculated by the product of velocity and cross-sectional area. Flow and stage height was manually measured at each visit to provide calibration and datum information and for the development of stage discharge relationships. The samplers were programmed to initiate the sampling program when the in-channel stage height exceeded the 'cease to flow' level. The 'cease to flow' stream level was determined through multiple field observations through the flow season. Once initiated the sampler was programmed to collect a sample every 3 hours. Discharge and loads were calculated using the Hydstra version 9 time-series analysis software (Hydstra/TS, 2007) when water quality and stage height time-series data were combined. In 2011 repeated failure of the height monitoring equipment made it impossible to determine the annual load.

All N and P analyses were performed with standard colorimetric methods (Rice, Bridgewater, APHA \& AWWA, 2012; Rayment \& Higginson, 1992) on a segmented flow auto-analyser (OI Analytical, College Station, Texas USA). Total $\mathrm{N}$ and $\mathrm{P}$ contents were determined from analysis of samples that had been digested to convert all $\mathrm{N}$ forms to nitrate, and all $\mathrm{P}$ forms to ortho-phosphate. Digestion was achieved after autoclaving $5 \mathrm{~mL}$ samples at $120^{\circ} \mathrm{C}$ for 30 minutes in a $1: 1 \mathrm{mix}$ of sample and $4 \%$ alkaline persulphate solution (Ebina, Tsutsui \& Shiriu, 1983). Nitrate N and Filterable Reactive P (FRP) were determined on filtered $(<0.45 \mu \mathrm{m})$ and undigested samples. Total Suspended Solids (TSS) was determined using a gravimetric filter paper method outlined by Grace Analytical Laboratory (1994). In 2011 only turbidity (Nephelometric Turbidity Unit, NTU) was analysed and this was converted to TSS $\left(\mathrm{mg} \mathrm{L}^{-1}\right)$ using the relationship derived by regression from earlier data $\left(\log _{10}\right.$ TSS $=-0.298+0.953 * \log _{10}$ turbidity, $\left.\mathrm{R}^{2}=0.84\right)$. 
The $\mathrm{P}$ sorption of the fresh gravel and gravel that had resided in the drain for 12 months was determined at $0 \mathrm{mg}$ $\mathrm{L}^{-1}$ and $0.7 \mathrm{mg} \mathrm{L}^{-1} \mathrm{P}$ solution concentration (the median concentration of the drainage water in the Veg section). The concentration of the $\mathrm{P}$ in solution was determined after gravel was left standing in the above solutions for 2 hours, 1 day, 2 days, 5 days and 12 days in a 20:1 solution to soil ratio (3 replicates). Gravel was left standing rather than shaken to avoid unrealistic $\mathrm{P}$ sorption measurements due to potential abrasion of gravel and exposure of fresh surfaces.

Exploratory data analysis was carried out using Data Desk (Velleman, 1997). Assessment of the data indicated that they were non-normally distributed, and therefore the data was often presented on log scales using notched box and whisker plots (Velleman \& Hoaglin, 1981; McGill, Tukey, \& Larsen, 1978), where the box depicts the central half of the data between the $25^{\text {th }}$ and $75^{\text {th }}$ percentiles, and the line across the box displays the median value. The whiskers extend from the 5 th to the $95^{\text {th }}$ percentiles. Values beyond the $5^{\text {th }}$ and $95^{\text {th }}$ percentiles (outliers) are plotted as a circle. Notches on the box and whisker plots approximately define the $95 \%$ confidence interval of the median (McGill et al., 1978). Visual assessment of notches on box and whisker displays for various treatments was used to assess the likelihood that population medians were different in preference to formal statistical treatments. Non-overlapping notches for different treatments could be regarded as being significantly different at the $95 \%$ level (Velleman \& Hoaglin, 1981), whilst formal statistical procedures such as ANOVA are beset by problems from pseudo replication, and serial correlation. Non-parametric measures such as median and $95 \%$ confidence interval of median are reported and discussed because of the skewed nature of the concentration data. The $95 \%$ confidence interval of the median was calculated using the half width method described by McGill et al. (1978).

The loads and flows measured from the upper catchment were subtracted from those from the lower catchment to reflect the losses only from the lower section of the drain. Although it is expected that there will be some interaction between the incoming $\mathrm{P}$ and the drain, the $\mathrm{P}$ concentration throughout the drainage system is relatively similar and the impact on the equilibrium will remain constant. The impact on loads would be mainly due to the characteristics of the drainage system measured here.

Along each drain section, composite samples of soil were taken at $0-5 \mathrm{~cm}$ below the drain bed surface, in the adjacent paddocks, and also within the vegetated area of the Veg drain. This shallow depth was used to measure stratified $\mathrm{P}$ in the drain bed material that can interact readily with streamflow, and allow direct comparison with soil in adjacent paddocks. Phosphorus Retention Index (PRI), a single point measure of the P sorption characteristics of a soil, was determined using the method described in Allen and Jeffery (1990). Organic carbon was measured using the Walkley and Black (1934) procedure, plant available P was measured using the Colwell (1965) method and TP analysis was determined on samples digested with sulfuric acid-potassium-copper sulphate and the P concentration measured colorimetrically at $880 \mathrm{~nm}$ as described by Allen and Jeffery (1990). Ammonium oxalate extractable iron $(\mathrm{AmOxFe})$ was also determined (Tamm, 1922). Whilst PRI estimates the amount of $\mathrm{P}$ sorption remaining in the soil, $\mathrm{AmOxFe}$ is a surrogate for the $\mathrm{P}$ sorption capacity that existed in the virgin soil prior to the application of $\mathrm{P}$. An estimate of $\mathrm{P}$ saturation was determined and expressed as the ratio of Colwell $\mathrm{P}$ to AmOxFe. This ratio indicates the proportion of binding sites (AmOxFe) that are occupied with Colwell P and is a simplification of that described by Kleinman, Bryant and Reid (1999).

\section{Results and Discussion}

The number of water samples collected at each site in any year varied from 40 to 310 (Table 1) depending upon the flow in the drainage system as influenced by the seasonal rainfall pattern. As the automatic samplers were triggered to pick up flow events, and the flow was higher in the downstream UF catchment, slightly more samples were collected there. The flow from the Veg catchment in 2006 was too low to be accurately calculated. The flow from both catchments was too low to be calculated in 2010 .

Table 1. Number of samples collected in 1997 to 2011 for assessment of water quality parameters $\left({ }^{*}\right.$ Cronin, 1998)

\begin{tabular}{ccc}
\hline Year & Veg & UF \\
\hline $1997^{*}$ & 11 & 11 \\
2006 & 83 & 101 \\
2007 & 244 & 310 \\
2008 & 55 & 70 \\
2009 & 48 & 40 \\
2011 & 210 & 192 \\
\hline
\end{tabular}




\subsection{Contaminant Concentration in Drainage Water}

\subsubsection{P Concentration}

In 1997, Cronin (1998) found the Veg drain discharging P with a lower TP than the UF section (Figure 2).

In contrast, the Veg section of drain discharged water with higher TP and FRP concentrations than the UF section over the monitoring period 2006-08 with no apparent difference in TP during 2009 (Figure 2). The median TP concentration (2006-2009) was $1.5 \pm 0.1 \mathrm{mg} \mathrm{L}^{-1}$ (median $\pm 95 \%$ confidence interval) and $1.4 \pm 0.1 \mathrm{mg} \mathrm{L}^{-1}$ in the Veg and UF sites respectively. Similarly the median FRP concentration (2006-2009) was higher in the Veg section $\left(1.1 \pm 0.1 \mathrm{mg} \mathrm{L}^{-1}\right)$ than it was in the UF section $\left(0.9 \pm 0.1 \mathrm{mg} \mathrm{L}^{-1}\right)$.

In 2011 after the addition of the cracked lateritic pea gravel to the Veg section of drain, TP and FRP) was lower than the UF section (Figure 2).

The ratio of FRP/TP concentrations from 2006 to 2009 appeared higher in the Veg section (71 $\pm 2 \%$ ) than in the UF $(63 \pm 2 \%)$. The FRP/TP concentration ratio from the 1997 measurements of Cronin (1998) showed $28 \pm 0.1 \%$ and $26 \pm 0.2 \%$ in the Veg and UF sections respectively. After gravel addition in 2011 the FRP/TP concentration ratio was $78 \pm 0.1 \%$ and $80 \pm 0.1 \%$ respectively in the Veg and UF sections.

Cronin (1998) interpreted the effect of reduced P flow from the Veg section of drain to be due to the vegetation but had noted that the Veg section of the drain had the bottom and sides of the drain scraped clean of vegetation and deposited sandy sediment by the drainage manager early on in the sampling period, exposing the clay subsoil.

It is now hypothesized that excavation of sediment in the Veg drain in 1997 exposed and disturbed fresh clay subsoil that could retain $\mathrm{P}$ and produced a less stable bed and bank. This increased suspended sediment and reduced the proportion of $\mathrm{P}$ attached to particulates, resulting in a much lower FRP/TP ratio. This would have the overall effect of reducing the TP concentration in the Veg section through both sorption to the drain bed and banks and re-sedimentation of sorbed P derived from the freshly destabilized drain relative to the UF section.

Similar results were found when dredged drainage ditches were compared with undredged drain sediments by Shigaki, Kleinman, Schmidt, Sharpley and Allen (2008) who found that added dissolved P would be removed from stream flow by freshly dredged drains. They found biological processes accounted for only $30 \%$ of the $\mathrm{P}$ removal in the dredged sediment. High residence times and sediment interaction can reduce nutrient losses in some drainage systems (Jarvie et al., 2008) and these conditions may occur further downstream. Keipert, Weaver, Summers, Clarke and Neville (2008) estimated that in the catchment of the Peel Inlet and Harvey Estuary, the loss of $\mathrm{P}$ from the paddock was substantially more than that which reaches the receiving water bodies. The sediment from the base of the drainage system may also become a source of nutrients (Whithers \& Sharpley, 2008).

Phosphorus retention on clay in the drain bed would be accentuated during low flows and less likely in higher flows during the sampling of Cronin (1998) because of shorter contact times. This was found to be the case where samples collected at higher flows had similar P concentrations at both sites.

After 9 years without maintenance (2006) the Veg drain bed and banks had stabilized and were covered with volunteer grasses, and had accumulated $\mathrm{P}$. The proportion of $\mathrm{P}$ attached to suspended sediment reduced (approx. $70 \%$ PP in 1997, approx. 30\% PP in the period 2006-2009), whilst the proportion of FRP increased (approx. 30\% FRP in 1997, approx. 70\% FRP in the period 2006-2009). The high TP and FRP/TP concentration ratio in the Veg section of drain measured from 2006 to 2009 , is most likely due to several factors including desorption of P that had accumulated in the drain, and reduced sorption of P discharged from adjacent paddocks. In contrast, the UF section was continuing to generate sediment due to livestock disturbing the drain banks and bed. This sediment in the UF section of drain was functioning to remove $\mathrm{P}$ through $\mathrm{P}$ sorption and re-sedimentation. The presence of vegetation appeared to have little effect on the overall retention of P. Rather, in this case, a positive impact of livestock to the UF section of drain appeared to be a modest reduction of the large FRP load. It is unlikely that the vegetation would have much opportunity to physically filter water discharged from paddocks because of feeder drains and low PP in surface runoff due to low slopes and sandy textured soils, which would favour leaching. The use of a similarly relatively small grassed waterway elsewhere had little effect on Dissolved Reactive P (DRP) (Fiener \& Auerswald 2009) and a review of the efficiency of buffers by Hoffman, et al. (2009) found highly variable effects of riparian buffers on DRP, noting DRP retention through to DRP release.

In 2011 the gravel provided a fresh sorbing surface for internal sources of FRP that could be released from accumulated $\mathrm{P}$ in the Veg drain, and from the FRP from the paddock. This had the effect of reducing FRP, and suspended sediment from the drain bed as the sediment was covered by the gravel. The overall reduction in $\mathrm{P}$ concentration from the use of gravel was less effective than excavating (exposing fresh subsoil and removing bed sediments) of the drain seen in 1997 by Cronin (1998). 


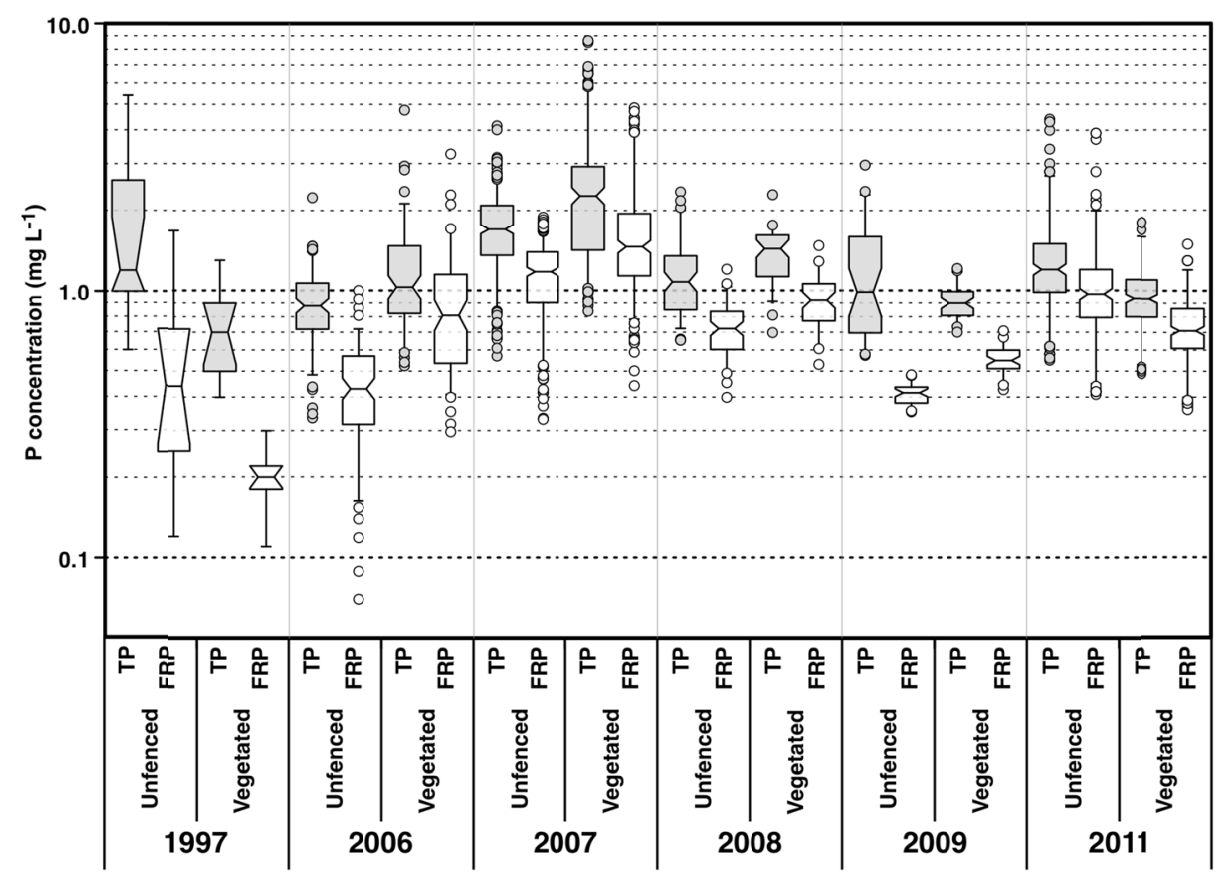

Figure 2. Notched box and whisker plots showing temporal variation in concentration (mg L $\left.{ }^{-1}\right)$ of TP (grey) and FRP (white) from the UF and Veg drains. Boxes show median, $25^{\text {th }}$ and $75^{\text {th }}$ percentiles. Whiskers range from $5^{\text {th }}$ to $95^{\text {th }}$ percentiles. Notches show $95 \%$ confidence interval of the median. Circles show outliers

\subsubsection{N Concentration}

The impact of vegetating the drain, clearing the drain out or adding gravel had little consistent impact on the $\mathrm{N}$ concentrations or forms in the drain.

In 1997 (Cronin, 1998) the median TN concentration was lower in the Veg section $\left(4.2 \pm 1 \mathrm{mg} \mathrm{L}^{-1}\right)$ than in the UF section $\left(6.0 \pm 0.8 \mathrm{mg} \mathrm{L}^{-1}\right)$. The median $\mathrm{NO}_{3}$ concentration was also lower in the Veg section $\left(1.1 \pm 0.8 \mathrm{mg} \mathrm{L}^{-1}\right)$ than in the UF section $\left(1.8 \pm 0.9 \mathrm{mg} \mathrm{L}^{-1}\right)$ (Figure 3).

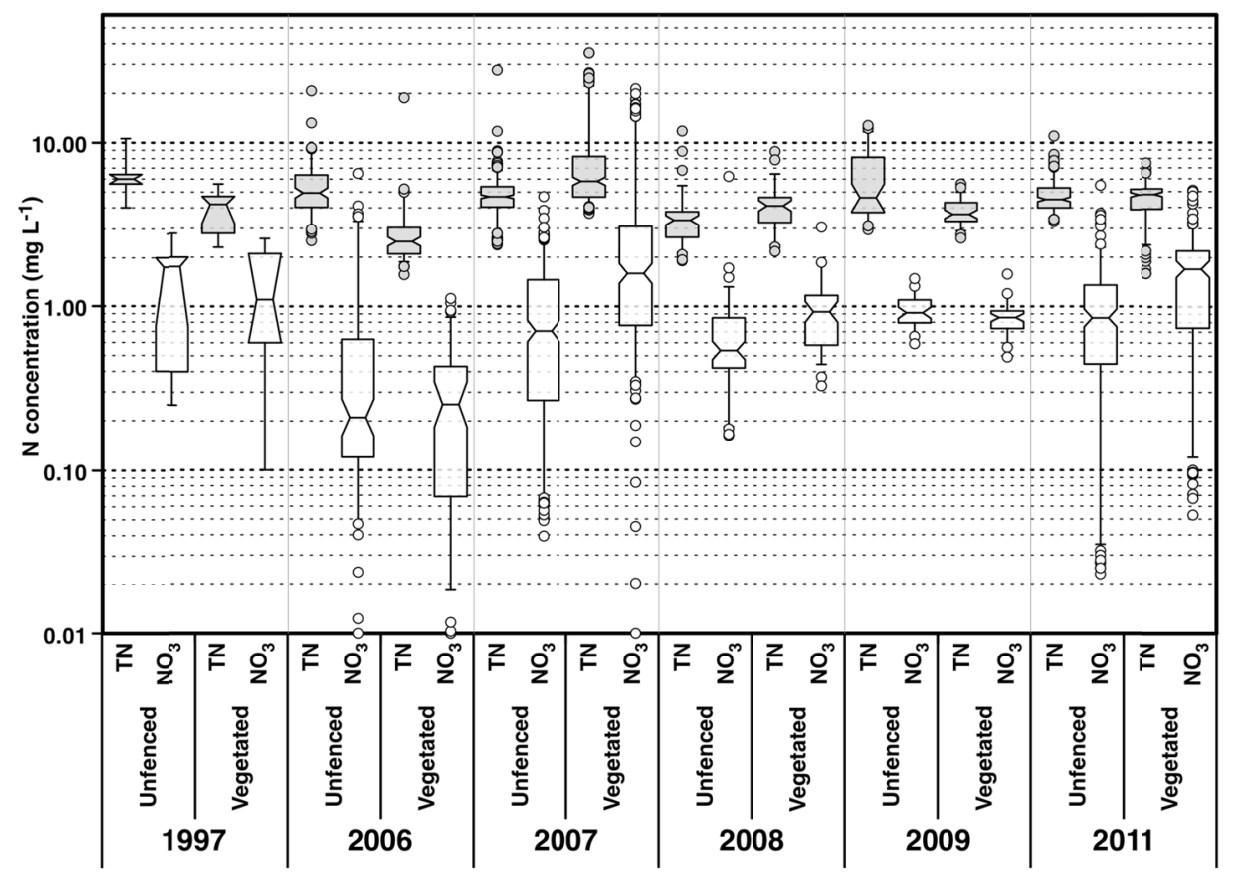

Figure 3. Notched box and whisker plots showing temporal variation in the concentration ( $\mathrm{m} \mathrm{L}^{-1}$ ) of TN (grey) and $\mathrm{NO}_{3}$ (white) from the UF and Veg drains. Boxes show median, $25^{\text {th }}$ and $75^{\text {th }}$ percentiles. Whiskers range from $5^{\text {th }}$ to $95^{\text {th }}$ percentiles. Notches show $95 \%$ confidence interval of the median. Circles show outliers 
Years of higher rainfall (2007 and 2008) resulted in increased TN and $\mathrm{NO}_{3}$ from the Veg site. In 2006 and 2009 there appeared to be a slight reduction in $\mathrm{TN}$ and $\mathrm{NO}_{3}$ when the rainfall was extremely low (Figure 3). From 2006 to 2009, the Veg section of drain discharged water with more $\mathrm{TN}$ and $\mathrm{NO}_{3}$ than the UF section.

The median TN concentration (2006 to 2009) was $3 \%$ higher in the Veg $\left(4.6 \pm 0.2 \mathrm{mg} \mathrm{L}^{-1}\right)$ than the UF site (4.5 \pm 0.1 $\left.\mathrm{mg} \mathrm{L}{ }^{-1}\right)$. The median $\mathrm{NO}_{3}$ concentration (2006 to 2009) was $34 \%$ higher in the Veg section $\left(0.9 \pm 0.1 \mathrm{mg} \mathrm{L}^{-1}\right)$ than it was in the UF section $\left(0.6 \pm 0.1 \mathrm{mg} \mathrm{L}^{-1}\right)$.

In 2011, after the addition of the lateritic gravel to the Veg section of drain, the Veg section was discharging a slightly higher median TN (Veg: $4.8 \pm 0.1$, UF: $4.5 \pm 0.2 \mathrm{mg} \mathrm{L}^{-1}$ ) and $\mathrm{NO}_{3}$ (Veg: $1.7 \pm 0.2$, UF: $0.85 \pm 0.1 \mathrm{mg} \mathrm{L}^{-1}$ ) than the UF section. This was similar to the $\mathrm{N}$ concentrations found in the period 2006 to 2009.

\subsubsection{TSS Concentration}

In 1997 the median TSS of the Veg and UF sections of the drain was $6 \pm 1$ and $75 \pm 37 \mathrm{mg} \mathrm{L}^{-1}$ respectively, or $92 \%$ less in the Veg drain (Cronin, 1998).

The excavation of the base of the Veg drain in 1997 still generated less sediment than the UF section. This suggests that the presence of cattle in the drain contributed to the measured sediment. The coarse textured sandy soils and low slopes in the catchment also supports the idea that very little sediment is contributed from paddock sources and the main source of sediment is therefore likely to be derived from exposed subsoils in the drain, and re-suspension of previously transported sediment in the drain. Fencing livestock out of the drain appeared to have more impact on sediment than the vegetation in the fenced area.

From 2006 to 2009 the UF section of the drain had TSS concentrations that were $65 \%$ greater than the Veg section of drain, with a median of $38 \pm 4$ and $23 \pm 2 \mathrm{mg} \mathrm{L}^{-1}$ respectively. The difference between the two sites was slightly less in the higher rainfall years of 2007 and 2008 (Figure 4).

In 2011, after the addition of the lateritic gravel to the Veg section of drain in 2010, the Veg section was discharging a lower TSS $(1.4 \pm 0.3)$ than the UF $\left(2.8 \pm 0.3 \mathrm{mg} \mathrm{L}^{-1}\right)$ section. The low TSS reflected the low rainfall during the winter of 2011, which also had a larger number of smaller rainfall events.

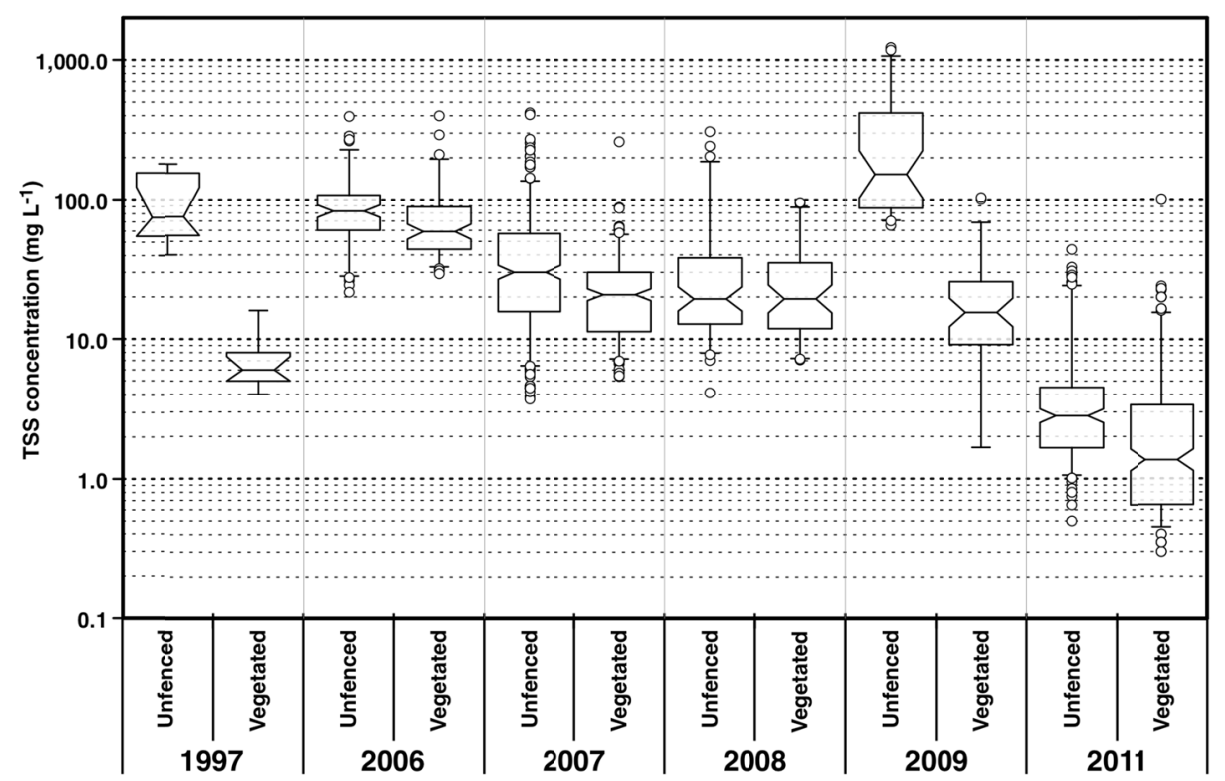

Figure 4. Notched box and whisker plots showing temporal variation in the TSS concentration $\left(\mathrm{mg} \mathrm{L}^{-1}\right)$ from the Unfenced and Vegetated drains. Boxes show median, $25^{\text {th }}$ and $75^{\text {th }}$ percentiles. Whiskers range from $5^{\text {th }}$ to $95^{\text {th }}$ percentiles. Notches show $95 \%$ confidence interval of the median. Circles show outliers

\subsection{Flow and Runoff}

There was slightly more runoff $(\mathrm{mm})$ from the upper Veg section of catchment compared with the UF catchment (Table 2). This may be due to a slightly greater depth of the Veg drain increasing runoff and flow speed. The 
shallower UF drain was wider and there may have been slightly more opportunity to pool the water and retain it in the soil of the catchment and drain.

Table 2. Cumulative and individual sub catchment area, flow and runoff for 2006 - 2011 (no flow in 2010)

\begin{tabular}{lccccccccccrrr}
\hline & & \multicolumn{1}{c}{$\begin{array}{c}\text { Area } \\
\text { (ha) }\end{array}$} & \multicolumn{4}{c}{ Flow (ML) } & \multicolumn{6}{c}{ Runoff (mm) } \\
\hline \multirow{2}{*}{ Cumulative } & Veg & 39 & 0 & 79 & 197 & 69 & 61 & 0 & 203 & 505 & 177 & 156 \\
Sub & UF & 130 & 10 & 208 & 522 & 108 & 73 & 8 & 160 & 402 & 83 & 56 \\
catchment & Veg & 39 & 0 & 79 & 197 & 69 & 61 & 0 & 203 & 505 & 177 & 156 \\
& UF & 91 & 10 & 129 & 325 & 39 & 12 & 11 & 142 & 357 & 43 & 31 \\
\hline
\end{tabular}

Runoff was characterised by two distinctly different seasons (Figure 5). The year 2006 was very dry with intermittent runoff lasting just over 1 month and the only site to receive measurable flow was the UF section of drain. In 2007 there was a more typical winter with close to average rainfall and runoff recorded at both sites between June and October. In 2008 the rainfall was $910 \mathrm{~mm}$ (only $97 \mathrm{~mm}$ below the average annual rainfall) and had the most runoff in the study. By 2009, the rainfall was $240 \mathrm{~mm}$ below the average annual rainfall and again did not produce as much runoff. In 2010 there was no runoff due to the extremely low rainfall. The annual rainfall in 2011 was closest to the long-term average. In 1997 when the previous study of the site was made by Cronin (1998) the rainfall was $792 \mathrm{~mm}$, which was similar to the rainfall of 2009 (Table 3).

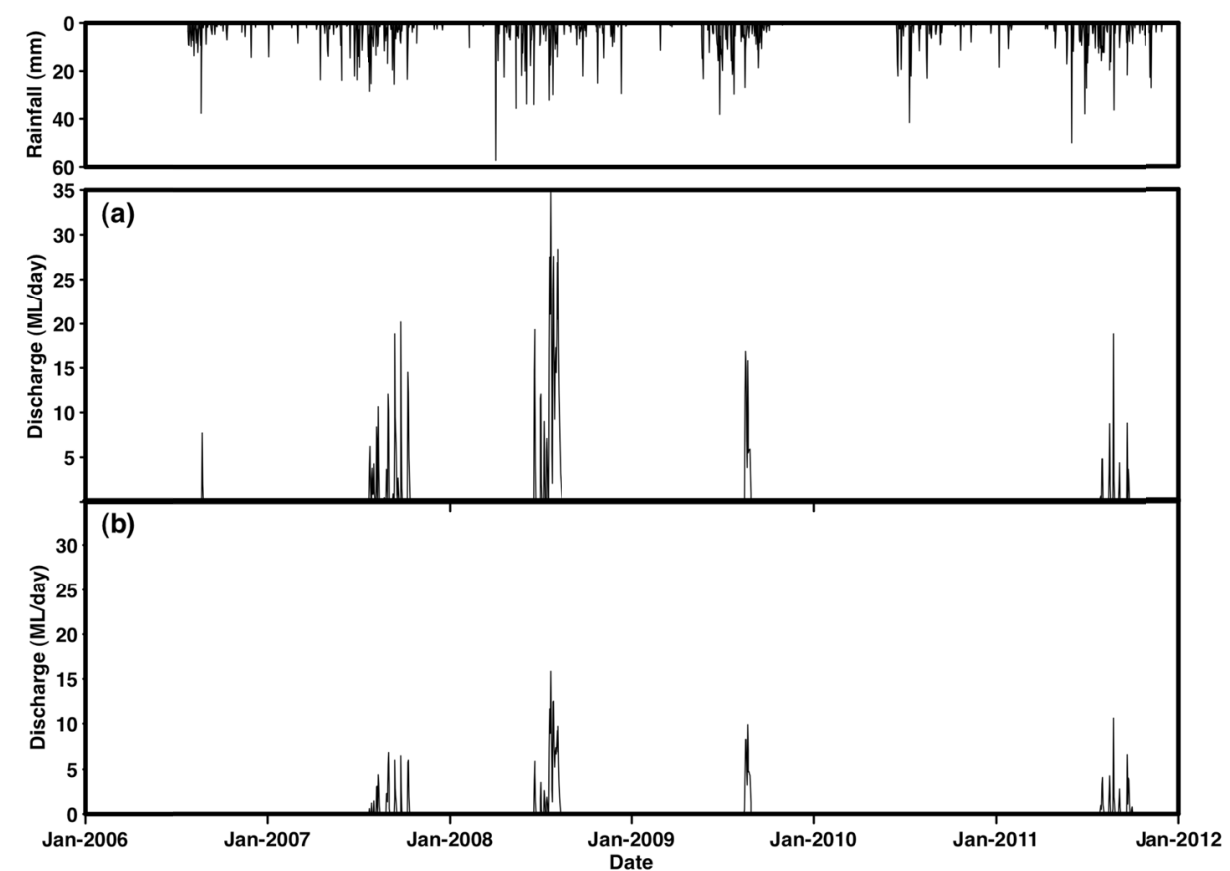

Figure 5. Rainfall (top), flow at the monitoring point below the UF section of drain (middle), flow at the monitoring point below the Veg section of drain (bottom)

Table 3. Annual rainfall during monitoring compared with the long-term average

\begin{tabular}{cccc}
\hline Year & Annual rainfall & Annual average rainfall & Relative to average \\
\hline 1997 & 792 & & -215 \\
2006 & 568 & & -439 \\
2007 & 882 & 1007 & -125 \\
2008 & 910 & & -97 \\
2009 & 767 & & -240 \\
2010 & 485 & & -522 \\
2011 & 946 & & -63 \\
\hline
\end{tabular}


During high rainfall periods in mid winter when the soil profile is saturated, $\mathrm{P}$ enters the drain over the surface mainly through saturation excess, overland flow. Surface runoff carries desorbed P from P saturated soil, mineralized P from organic matter, low molecular weight organic $\mathrm{P}$ and $\mathrm{P}$ dissolved from current and previous fertilizer residues shown by the high proportion of FRP in the runoff. During low rainfall periods when the soil profile is not saturated, $\mathrm{P}$ may enter the drain via leaching and subsurface pathways. However under these conditions it is likely that less $\mathrm{P}$ enters the drain since interaction with the $\mathrm{P}$ retentive subsoil would reduce $\mathrm{P}$ transport. During these periods the drain sediments themselves may become sources of $\mathrm{P}$ as they have the same TP content as those in the paddock (Table 7), and much more Colwell P. Alternatively, P sourced from the topsoil may bypass the subsoil through macro-pore flow and directly enter the drain. All of these mechanisms preclude substantial interaction with vegetation on the banks of the drainage system. In 1997 the sediment of the Veg section of drain was freshly exposed during excavation and was likely to have very low levels of P. However, by 2006, the P in the sediment in the drain bed of this Veg section of drain was found to be similar to that of the surrounding paddock. This potential accumulation of $\mathrm{P}$ in the drain bed may explain the earlier observations of Cronin (1998) where P was retained in the Veg drain. Additionally it is clear from the FRP/TP concentration ratios (approx. 30\% in 1997, approx. 70\% in 2006 to 2009, approx. 80\% in 2011) that in-drain sediment supply due to management can alter the form of P measured in the drain. In these sandy catchments it is likely that soluble forms of $\mathrm{P}$ are supplied from adjacent agricultural soils, which is then transformed to particulate $\mathrm{P}$ dependent on sediment supply (Weaver \& Summers, 2014).

\subsection{Nutrient Loads}

The unit area TP and FRP discharge $\left(\mathrm{kg} \mathrm{ha}^{-1}\right)$ of the Veg section of drain was more than double the UF section (Table 4).

The form of P appeared to be transformed slightly from FRP to PP during transport from the Veg to the UF area. Over the entire monitoring period the FRP/TP load ratio from the Veg area averaged $68 \%$ compared to $61 \%$ in the UF area.

Table 4. Phosphorus loads for individual sub-catchments for 2006 to 2011 (39 and 91 ha Veg and UF respectively)

\begin{tabular}{|c|c|c|c|c|c|c|c|c|c|c|c|c|c|c|}
\hline \multirow[t]{2}{*}{ Year } & \multicolumn{2}{|c|}{$\begin{array}{c}\mathrm{TP} \\
(\mathrm{kg})\end{array}$} & \multicolumn{2}{|c|}{$\begin{array}{c}\text { TP } \\
\left(\mathrm{kg} \mathrm{ha}^{-1}\right)\end{array}$} & \multicolumn{2}{|c|}{$\begin{array}{l}\text { FRP } \\
(\mathrm{kg})\end{array}$} & \multicolumn{2}{|c|}{$\begin{array}{c}\text { FRP } \\
\left(\mathrm{kg} \mathrm{ha}^{-1}\right)\end{array}$} & \multicolumn{2}{|c|}{$\begin{array}{l}\mathrm{PP}^{*} \\
(\mathrm{~kg})\end{array}$} & \multicolumn{2}{|c|}{$\begin{array}{c}\mathrm{PP}^{*} \\
\left(\mathrm{~kg} \mathrm{ha}^{-1}\right)\end{array}$} & \multicolumn{2}{|c|}{$\begin{array}{c}\mathrm{FRP} / \mathrm{TP} \\
(\%)\end{array}$} \\
\hline & $\stackrel{\infty}{>}^{\infty}$ & 岁 & $\stackrel{\infty}{>}^{\infty}$ & 岇 & $\stackrel{\infty}{\infty}^{\infty}$ & 㟔 & $\stackrel{\infty}{D}^{\infty}$ & 岇 & $\stackrel{\infty}{>}^{\infty}$ & 岇 & $\stackrel{\infty}{>}^{\infty}$ & 与 & $\sum^{\infty}$ & 㟔 \\
\hline 2006 & 0 & 12 & 0.00 & 0.13 & 0 & 8 & 0.00 & 0.09 & 0 & 4 & 0.00 & 0.04 & - & 69 \\
\hline 2007 & 218 & 158 & 5.59 & 1.74 & 150 & 91 & 3.85 & 1.00 & 68 & 67 & 1.74 & 0.74 & 69 & 57 \\
\hline 2008 & 242 & 224 & 6.21 & 2.46 & 157 & 168 & 4.03 & 1.85 & 85 & 56 & 2.18 & 0.62 & 65 & 75 \\
\hline 2009 & 48 & 71 & 1.23 & 0.78 & 28 & 7 & 0.72 & 0.08 & 20 & 64 & 0.51 & 0.70 & 59 & 10 \\
\hline 2011 & 62 & 30 & 1.58 & 0.33 & 48 & 28 & 1.25 & 0.31 & 14 & 2 & 0.36 & 0.02 & 79 & 94 \\
\hline Ave & 114 & 99 & 2.92 & 1.09 & 77 & 60 & 1.97 & 0.66 & 37 & 39 & 0.96 & 0.42 & 68 & 61 \\
\hline
\end{tabular}

* Particulate P (PP) was derived by subtraction of Filterable Reactive P (FRP) from Total P (TP).

The $\mathrm{TN}$ and $\mathrm{NO}_{3}$ load per unit area $\left(\mathrm{kg} \mathrm{ha}^{-1}\right)$ from the Veg section of drain was more than double that measured in the UF section (Table 5). The proportion of unit area TN $\left(\mathrm{kg} \mathrm{ha}^{-1}\right)$ measured as nitrate was $30 \%$ from the Veg area and $19 \%$ from the UF area. 
Table 5. Total N loads for the individual catchments from 2006 to 2011 (39 and 91 ha Veg and UF respectively)

\begin{tabular}{|c|c|c|c|c|c|c|c|c|}
\hline \multirow[t]{2}{*}{ Year } & \multicolumn{2}{|c|}{$\mathrm{TN}(\mathrm{kg})$} & \multicolumn{2}{|c|}{ TN $\left(\mathrm{kg} \mathrm{ha}^{-1}\right)$} & \multicolumn{2}{|c|}{$\mathrm{NO}_{3} \mathrm{~N}(\mathrm{~kg})$} & \multicolumn{2}{|c|}{$\mathrm{NO}_{3} \mathrm{~N}\left(\mathrm{~kg} \mathrm{ha}^{-1}\right)$} \\
\hline & $\stackrel{\infty}{>}$ & 岇 & $\stackrel{\infty}{\infty}^{\infty}$ & 岁 & $\stackrel{\infty}{\infty}^{\infty}$ & 岇 & $\stackrel{\infty}{\infty}^{\infty}$ & 岇 \\
\hline 2006 & 0 & 41 & 0.00 & 0.45 & $\overline{0}$ & 1.7 & 0.00 & 0.02 \\
\hline 2007 & 666 & 361 & 17.1 & 3.97 & 274 & 71 & 7.03 & 0.78 \\
\hline 2008 & 697 & 824 & 17.9 & 9.05 & 184 & 159 & 4.72 & 1.75 \\
\hline 2009 & 190 & 344 & 4.87 & 3.78 & 37 & 40 & 0.95 & 0.44 \\
\hline 2011 & 273 & 102 & 7 & 1.12 & 51 & 51 & 1.31 & 0.56 \\
\hline Ave & 365 & 334 & 9.37 & 3.67 & 109 & 65 & 2.80 & 0.71 \\
\hline
\end{tabular}

\subsection{Sediment}

When catchments are considered separately, the UF drain produced $48 \%$ higher TSS unit area loads $\left(\mathrm{kg} \mathrm{ha}^{-1}\right)$. The cumulative loads show the scale of the deterioration in the UF section of drain where nearly 3.5 times as much sediment was discharged from 2006 to 2011 compared to the Veg section. In the $820 \mathrm{~m}$ of UF drain TSS increased by over $17000 \mathrm{~kg}$ in 2009 alone (Table 6).

This increase in sediment in the water column and the resulting exposure of fresh material in the drain bed may have allowed greater binding and retention of $\mathrm{P}$.

Table 6. Suspended sediment loads for the individual catchments from 2006 to 2011 (39 and 91 ha Veg and UF respectively)

\begin{tabular}{rrrrr}
\hline Year & \multicolumn{2}{c}{ TSS (kg) } & \multicolumn{2}{c}{ TSS (kg ha $\left.{ }^{-1}\right)$} \\
\cline { 2 - 5 } & Veg (39 ha) & UF (91 ha) & Veg (39 ha) & UF (91 ha) \\
\hline 2006 & 0 & 818 & 0 & 9 \\
2007 & 2171 & 11361 & 56 & 125 \\
2008 & 6796 & 6673 & 174 & 73 \\
2009 & 1831 & 18845 & 47 & 207 \\
2011 & 165 & 30 & 4.2 & 0.32 \\
\hline Ave & 2192 & 7545 & 56 & 83 \\
\hline
\end{tabular}

\subsection{Soil, Drain-Bed Sediment and Lateritic Gravel}

The TP in paddock soil and drain sediment was the same for both the Veg and UF sections of drain, whilst there was an increase in Colwell $\mathrm{P}$ in sediment for both sections of the drain relative to the paddock indicating that there had been a build-up of $\mathrm{P}$ sorbed in drain sediment (Table 7). The soil within the riparian buffer of the Veg section was lower in TP and Colwell P than all of the other sites sampled (Table 7). This suggests that little P is accumulating in this zone due to either deposition of soil particulates, or sorption of FRP from paddock runoff.

The PRI of the sediment in both the Veg and the UF section of drain was the same and also positive indicating that the sediment may adsorb $\mathrm{P}$ if $\mathrm{P}$ enriched water was in contact with the sediment for sufficient time. The initial potential for P sorption of the soils before fertilizing is represented by AmOxFe and shows that the UF paddocks were higher than Veg paddocks. The PRI is also higher suggesting that the paddock around the UF drain is less likely to discharge dissolved P than that around the Veg drain.

The soil in the paddock surrounding the Veg section of the drain had higher P saturation, lower PRI and lower AmOxFe than the paddock around the UF drain. This may have contributed to lower $\mathrm{P}$ in runoff into the UF drain due to the higher P sorption if drainage water travels across or through the surface layer.

The PRI of the fresh gravel was 1.9 and the PRI after being exposed to drainage water for 12 months was $<0.1$. Although this was lower than in the sediment in the drain (PRI 12), the sediment was saturated with P shown by the Colwell P/AmOxFe ratio (Table 7). Covering the sediment with a $30 \mathrm{~mm}$ layer of sorbing gravel would restrict circulation with the drain water reducing $\mathrm{P}$ desorption from the sediment in the drain bed. 
The lateritic gravel appears to be only of value in retaining nutrients in the short term. When the gravel was exposed to the median P concentration of the Veg section of drain of $0.7 \mathrm{mg} \mathrm{L}^{-1}$, fresh gravel strongly sorbed $\mathrm{P}$, but gravel that had been in the drain after only one winter slightly desorbed P showing its P sorbing capacity was exhausted (Figure 6). When this used and exhausted gravel was exposed to water without $\mathrm{P}$ it became strongly desorbing indicating that if catchment actions were successful in halting $\mathrm{P}$ entering the drain, then the drain sediment would become a source of $\mathrm{P}$ as the equilibrium was reversed (Figure 6).

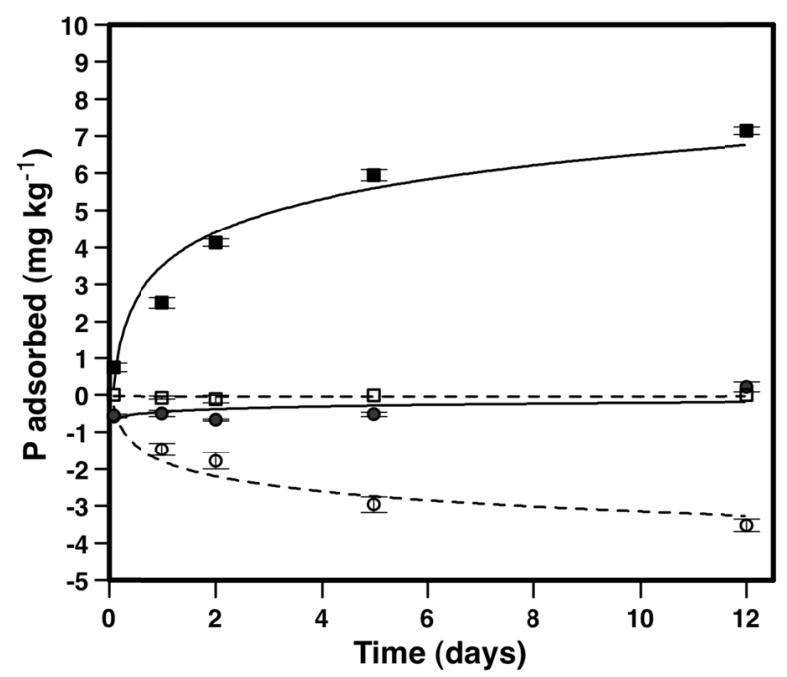

Figure 6. Phosphorus sorption over time for lateritic gravel taken from the drain (dashed lines and open symbols) and fresh unused lateritic gravel (solid lines and closed symbols). Squares are at an initial solution concentration $0.7 \mathrm{mg} \mathrm{P} \mathrm{L}^{-1}$ and the circles are at an initial solution concentration of $0 \mathrm{mg} \mathrm{P} \mathrm{L}^{-1}$ (error bars are standard errors of the means)

The runoff from farmed paddocks has carried with it $\mathrm{P}$ from paddocks into the drainage system where it travels downstream and accumulates in the drain-bed sediment at concentrations and degrees of saturation similar to that found in the paddock (Table 7).

The soil under the vegetation had a much lower capacity to retain $P$ than the paddocks or the drain-bed sediments shown by the low PRI and AmOxFe. This area may not be a sink for $\mathrm{P}$ because the capacity of the soil to retain $\mathrm{P}$ is very low or the interaction between the surface water flow was limited by it being on a slightly raised spoil bank.

Table 7. Median soil characteristics from the paddock surrounding the drain, the sediment in the drain bed and the soil inside the fenced and vegetated area

\begin{tabular}{cccccc}
\hline & \multicolumn{2}{c}{ Paddock soil } & \multicolumn{2}{c}{ Drain bed } & Within the vegetated area \\
& \multicolumn{2}{c}{$(0-50 \mathrm{~mm})$} & $(0-50 \mathrm{~mm})$ & $(0-50 \mathrm{~mm})$ \\
\hline & Veg & UF & Veg & UF & Veg \\
$\mathrm{TP}\left(\mathrm{mg} \mathrm{kg}^{-1}\right)$ & $387^{\mathrm{a}}$ & $435^{\text {a }}$ & $506^{\mathrm{a}}$ & $357^{\mathrm{a}}$ & $91^{\mathrm{b}}$ \\
Colwell P $\left(\mathrm{mg} \mathrm{kg}^{-1}\right)$ & $70^{\mathrm{a}}$ & $53^{\mathrm{a}}$ & $156^{\mathrm{b}}$ & $129^{\mathrm{b}}$ & $15^{\mathrm{c}}$ \\
PRI & $1.9^{\mathrm{bcd}}$ & $42^{\mathrm{a}}$ & $12^{\text {acd }}$ & $7.4^{\mathrm{ad}}$ & $1.2^{\mathrm{b}}$ \\
AmOxFe $\left(\mathrm{mg} \mathrm{kg}^{-1}\right)$ & $1402^{\mathrm{b}}$ & $4490^{\mathrm{c}}$ & $861^{\mathrm{bc}}$ & $1557^{\mathrm{b}}$ & $127^{\mathrm{a}}$ \\
Colwell P/AmOxFe ratio(\%) & $7.1^{\mathrm{a}}$ & $1.6^{\mathrm{b}}$ & $12.9^{\mathrm{a}}$ & $7.7^{\mathrm{a}}$ & $9.5^{\mathrm{a}}$ \\
Organic carbon $(\%)$ & $3.5^{\mathrm{a}}$ & $3.6^{\mathrm{a}}$ & $3.6^{\mathrm{a}}$ & $3.5^{\mathrm{a}}$ & $2.9^{\mathrm{b}}$ \\
\hline
\end{tabular}

Within a row, treatments with different letters are different when means of log transformed values are compared $\mathrm{P}<0.05$.

The catchment surrounding the drain had more P (as single superphosphate) applied than the section. This may have contributed to more $\mathrm{P}$ being lost from the catchment 
The artificial drainage system investigated here is slightly more incised than that of natural streams occurring in the region, hence there may be differences in the effectiveness of riparian management to control nutrients where the banks of natural streams have a lower slope. Additionally the site was only vegetated on one side, making comparison with riparian management with vegetation on both sides difficult. These aspects were controlled by McKergow et al. (2003) in a sandy catchment near Albany Western Australia where they found a similar impact of riparian management that significantly reduced sediment transport, but allowed the passage of the majority of the $\mathrm{P}$ in a soluble form. Similarly they also found that during a period where the stream was unfenced and unvegetated a higher proportion of P was attached to sediment. McKergow et al. (2003) also showed no difference in TP loads before and after riparian management was implemented.

In these flat sandy soil catchments, water discharges mainly over P saturated surface soils during winter, and also travels through superficial subsurface pathways, interacting with soil that may be saturated with $\mathrm{P}$. The dominant form of $\mathrm{P}$ that reaches the riparian zone is soluble or bound to extremely small particulates $(<0.45 \mu \mathrm{m})$, which are not physically filtered by vegetation or retained through sedimentation. Although the sediment in the Veg drain had some remaining P retention as shown by PRI, the residence time, degree of contact, and P sorption capacity appears to be insufficient to retain all the soluble $\mathrm{P}$ in the drain base sediment. The main mechanism remaining for the riparian zone is to take up P during transpiration, which is clearly inadequate as shown by the presence of runoff water. This mechanism of uptake is also limited due to the low P requirement of mature native vegetation. Less than 1 hectare of riparian vegetation is present in the Veg catchment contributing to approximately $3 \mathrm{~kg} \mathrm{ha}^{-1} \mathrm{yr}^{-1}$ of P uptake (Attiwill, 1980), or $6 \mathrm{~kg} \mathrm{ha}^{-1} \mathrm{yr}^{-1}$ if both sides were vegetated. The retention of only $3-6 \mathrm{~kg} \mathrm{ha}^{-1} \mathrm{yr}^{-1}$ in plant growth is also inadequate considering the annual average FRP runoff of $77 \mathrm{~kg}$, hence the impact due to P uptake from riparian vegetation is unlikely to be detected. The relatively low concentration of $P$ in the soil of the vegetated area of the drain banks is another indication of the lack of retention of $\mathrm{P}$ in this area and the lack of interaction of this area with surface flows of water entering the drain. The area which is selected to be vegetated needs to be carefully considered because the water appears to be by-passing this region at many points of concentrated flow rather than as sheet flow around the drain sides. This effect may be reduced in natural drainage systems that are less incised and where the banks flood more, but the form of $\mathrm{P}$ in the water entering the drain must also be considered.

A number of factors such as differing fertilization or slightly different drain incision may have contributed to differences, or lack of them reported here.

Although this was not an ideally controlled trial, the apparent reductions in P load from a catchment with riparian vegetation could not be replicated, nor could the anticipated or documented reductions in P load found elsewhere in the literature.

\section{Conclusion}

This fenced drain with well established riparian vegetation increased channel stability and the capture of sediment in runoff, reducing sediment load by more than $27 \mathrm{~kg} \mathrm{ha}^{-1}$. However, there was little measurable impact on the $\mathrm{P}$ concentration and appeared to have little impact in retaining $\mathrm{P}$ in soluble forms.

$P$ retention was reduced most by mechanical exposure of the drain bed, followed by livestock exposing the drain bed and vegetation appeared to have little impact. Fencing appeared to have a greater impact on sediment retention than the vegetation even when the drain bed was scraped during maintenance. The vegetation appeared to have little impact on $\mathrm{P}$ or sediment retention.

The results suggest that the absence of fencing allowed livestock to mobilise sediment and expose fresh sorbing drain-bed surfaces, which interacted with and retained soluble $\mathrm{P}$ entering drains from adjacent paddocks. There was also a small amount of conversion of the soluble $\mathrm{P}$ to particulate $\mathrm{P}$ forms in the drain, and subsequent retention over the length of the UF reach of drain.

In these flat sandy catchments, fencing and re-establishment of riparian vegetation appears useful in stream stability and particulate retention but of limited or minor value for nutrient retention where $\mathrm{P}$ is not in a particulate form or where vegetation has little interaction with drainage water. Other techniques and mechanisms would need to be employed to reduce nutrient loads. These results also suggest that regularly cleaning out fenced sections of drains performs the dual function of retaining P and reducing the generation of sediment. Similarly, alternate sections of unfenced and vegetated drains may be partially successful in generating nutrient sorbing drain-bed sediment followed by fenced drains designed to trap the generated suspended sediment. Additionally, cracked lateritic pea gravel can retain some soluble $\mathrm{P}$ when placed in the stream, but this appears to only be a short-term solution.

Alternatively, the use of fencing with or without revegetation needs to accompany the use of inorganic nutrient retentive materials either on the paddock or in the drainage system to retain the soluble or low molecular weight 
organic forms of $\mathrm{P}$ on-site. This would enable other potential environmental benefits of revegetation to be combined with maximum improvement in water quality.

The impact of this assessment of a first order drain must also be considered in the context of the entire drainage system. This needs to be understood and taken into account and targeted intervention in the drainage system may be needed to maximize the impact of the drainage system on improving the water quality.

\section{Acknowledgements}

The role of the landholders of the Pitter and Nancarrow families of Coolup are gratefully acknowledged for their tireless assistance and cooperation over the years of the study. Also, of importance is the assistance of Mark Rivers, Martin Clark, Tony Allen, and Fred Robinson for establishing and operating site equipment. Financial and in-kind assistance from the Peel-Harvey Catchment Council, the Department of Agriculture and Food, WA and the Department of Water through with support from the Australian Government and the WA Government.

\section{References}

Allen, D. G., \& Jeffrey, R. C. (1990). Methods for analysis of phosphorus. Western Australian Soil Report of Investigation No.37 Chemistry Centre WA, p. 37, cited in Burkitt L. L., Moody P. W., Gourley C. J. P., Hannah M. C. (2002) A simple phosphorus buffering index for Australian soils. Australian Journal of Soil Research, 40, 497-513. http://dx.doi.org/10.1071/SR01050

Attiwill, P. M. (1980). Nutrient cycling in a Eucalyptus Obliqua (L'herit) forest [in Victoria] iv Nutrient uptake and nutrient return. Australian Journal of Botany, 28, 199-222. http://dx.doi.org/10.1071/BT9800199

Bolland, M. D. A., Russell, B., \& Weaver, D. M. (2010). Phosphorus for high rainfall pastures. Bulletin 4808. Department of Agriculture and Food Western Australia. Retrieved from http://www.agric.wa.gov.au/objtwr /imported_assets/content/past/bn_phosphorus_high_rainfall_pastures.pdf. Accessed 28 August 2014

Colwell, J. D. (1965). An automated procedure for determination of phosphorus in sodium hydrogen carbonate extracts of soils. Chem Ind, 22(May), 893-895.

Cronin, D. (1998). The Effectiveness of 'Streamlining' in Improving the Water Quality of Agricultural Drains in the Peel-Harvey Catchment, Western Australia. School of Biological and Environmental Science, MSc thesis. Murdoch University, Perth Western Australia.

Drewry, J. J, Newham, L. T. H., Greene, R. S. B., Jakeman, A. J., \& Croke, B. F. W. (2006). A review of nitrogen and phosphorus export to waterways: context for catchment modelling. Marine and Freshwater Research, 57, 757-774. http://dx.doi.org/10.1071/MF05166

Ebina, J., Tsutsui, T., \& Shiriu, T. (1983). Simultaneous determination of total nitrogen and total phosphorus in water using peroxidisulphate oxidation. Water Research, 17, 1721-1726. http://dx.doi.org/10.1016/0043-1354(83)90192-6

Environmental Protection Agency. (2008). Water Quality Improvement Plan for the Rivers and Estuary of the Peel-Harvey System, Environmental Protection Authority, Perth Western Australia. http://www.epa.wa.gov.au/Policies_guidelines/other/Pages/phwqip.aspx. Accessed 22 September 2014.

Fiener, P., \& Auerswald, K. (2009). Effects of Hydrodynamically Rough Grassed Waterways on Dissolved Reactive Phosphorus Loads Coming from Agricultural Watersheds. Journal of Environmental Quality, 38, 548-559. http://dx.doi.org/10.1016/j.ecoleng.2006.02.005

Grace Analytical Laboratory. (1994). Standard Operating Procedure for the Sampling and Analysis of Total Suspended Solids in Great Lakes Waters. Chicago, IL 60605, August 2, 1994, viewed 30 September 2008. Retrieved August 28, 2014, from http://www.epa.gov/glnpo/lmmb/methods/tss2.pdf

Hodgkin, E. P., Birch, P. B., Black, R. E., \& Humphries, R. B. (1980). The Peel-Harvey Estuarine System Study, 1976-80. Department of Environment and Conservation, Perth, Report No. 9.

Hoffmann, C. C., Kjaergaard, C., Uusi-Kämppäc, J., Hansend, H. C. B., \& Kronvang, B. (2009). Phosphorus Retention in Riparian Buffers: Review of Their Efficiency. Journal of Environmental Quality, 38, 1942-1955. http://dx.doi.org/10.2134/jeq2008.0087

Hydstra/TS. (2007). Hydstra Time-Series Data Management Software Package, Kisters Pty Ltd.

Jarvie, H. P., Withers, P. J., Hodgkinson, R., Bates, A., Neal, M., Wickham, H. D., ... Armstrong, L. (2008). Influence of Rural Land Use on Streamwater Nutrients and Their Ecological Significance. Journal of Hydrology, 350, 166-186. http://dx.doi.org/10.1016/j.jhydrol.2007.10.042 
Keipert, N., Weaver D. M., Summers, R. N., Clarke, M., \& Neville S. (2008). Guiding BMP adoption to improve water quality in various estuarine ecosystems in Western Australia. Water Science and Technology, 57, 1749-1756. http://dx.doi.org/10.2166/wst.2008.276

Kleinman, P. J. A., Bryant, R. B., \& Reid, W. S. (1999). Development of pedotransfer functions to quantify phosphorus saturation of agricultural soils. Journal of Environmental Quality, 28, 2026-2030. http://dx.doi.org/10.2134/jeq1999.00472425002800060044x

McComb, A. J., \& Davis, D. A. (1993). Eutrophic Waters of Southwestern Australia. Fertilizer Research, 36, 105-114. http://dx.doi.org/10.1007/BF00747580

McGill, R., Tukey, J. W., \& Larsen, W. A. (1978). Variations of Box Plots. The American Statistician, 32, 12-16. http://dx.doi.org/10.2307/2683468

McKergow, L. A., Prosser, I. P., Weaver, D. M., Grayson, R. B., \& Reed, A. E. G. (2006a). Performance of grass and eucalyptus riparian buffers in a pasture catchment, Western Australia, part 1: riparian hydrology. Hydrological Processes, 20, 2309-2326. http://dx.doi.org/10.1002/hyp.6053

McKergow, L. A., Prosser, I. P., Weaver, D. M., Grayson, R. B., \& Reed, A. E. G. (2006b). Performance of grass and eucalyptus riparian buffers in a pasture catchment, Western Australia, part 2: water quality. Hydrological Processes, 20, 2327-2346. http://dx.doi.org/10.1002/hyp.6054

McKergow, L. A., Weaver, D. M., Prosser, I. P., Grayson, R. B., \& Reed, A. E. G. (2003). Before and after riparian management: sediment and nutrient exports from a small agricultural catchment, Western Australia. Journal of Hydrology, 270, 253-272. http://dx.doi.org/10.1016/S0022-1694(02)00286-X

Osborne, L. L., \& Kovacic, D. A. (1993). Riparian vegetated buffer strips in water quality restoration and stream management. Freshwater Biology, 29, 243-258. http://dx.doi.org/10.1111/j.1365-2427.1993.tb00761.x

Rayment, G. E., \& Higginson, F. R. (1992). Phosphorus Australian Laboratory Handbook of Soil and Water Chemical Methods (Volume 3, pp. 68-70). Melbourne: Australian soil and land survey handbook Inkata Press. http://nla.gov.au/nla.cat-vn685915

Rice, E. W., Bridgewater, L., APHA, \& AWWA (2012). Standard methods for the examination of water and wastewater (19th ed.). Greenberg A. E. (Ed.). American Public Health Association, American Water Works Association and Water Environment Federation. Washington D.C. USA. ISBN 9780875530130.

Shigaki, F., Kleinman, P. J. A., Schmidt, J. P., Sharpley, A. N., \& Allen, A. L. (2008). Impact of Dredging on Phosphorus Transport in Agricultural Drainage Ditches of the Atlantic Coastal Plain. Journal of the American Water Resources Association, 44, 1500-1511. http://dx.doi.org/10.1111/j.1752-1688.2008.00254.x

Tamm, O. (1922). Eine Methode zur Bestimmung de der anorganischen Komponente des Bodens. Meddelanden fran Statens skogsforsoksanstalt Stockholm, 19, 387-404.

Thorne, C. R. (1990). Effects of vegetation on riverbank erosion and stability. In: Vegetation and Erosion: Processes and Environments. New York: Wiley.

Velleman, P. F. (1997). Data Desk Version 6.0. Statistics Guide Vol. 3, Data Description Inc, PO Box 4555 Ithaca, NY. Retrieved from http://www.datadesk.com accessed 22 Sept 2014

Velleman, P. F., \& Hoaglin, D. C. (1981). Applications, Basics and Computing of Exploratory Data Analysis. Boston: Duxbury Press.

Weaver, D. M., \& Summers, R. N. (2014). Fit-for-purpose phosphorus management: do riparian buffers qualify in catchments with sandy soils? Environmental Monitoring and Assessment, 186, 2867-2884. http://dx.doi.org/10.1007/s10661-013-3586-4

Weaver, D. M., Ritchie, G. S. P., \& Gilkes, R. J. (1992). Phosphorus sorption by gravels in lateritic soils. Australian Journal of Soil Research, 30, 319-30. http://dx.doi.org/10.1071/SR9920319

Withers, P. A., \& Sharpley, A. N. (2008). Characterization and Apportionment of Nutrient and Sediment Sources in Catchments. Journal of Hydrology, 350, 127-130. http://dx.doi.org/10.1016/j.jhydrol.2007.10.054

\section{Copyrights}

Copyright for this article is retained by the author(s), with first publication rights granted to the journal.

This is an open-access article distributed under the terms and conditions of the Creative Commons Attribution license (http://creativecommons.org/licenses/by/3.0/). 